\title{
Pelatihan dan Pengetahuan Tentang Perpajakan Secara Online Di Era Pandemi Covid 19
}

\author{
Yana Hendayana $^{1}$, Suskim Riantani ${ }^{2}$, Wien Dyahrini ${ }^{3}$ \\ ${ }^{1,2,3}$ Universitas Widyatama, Bandung, Indonesia \\ yana.hendayana@widyatama.ac.id, suskim.riantani@widyatama.ac.id, \\ wien.dyahrini@widyatama.ac.id
}

\begin{abstract}
Abstrak
Tingkat permasalahan pengetahuan dan pemahaman wajib pajak (khususnya pelaku UMKM di Jawa Barat) mengenai adanya stimulus pajak yang diberikan pemerintah dimasa pandemi covid 19 ini masih rendah. Sebagian besar UMKM belum mengetahui dan memahami serta memanfaatkan tentang adanya insentif pajak yang diberikan oleh pemerintah melalui PMK 86/2020. Diperlukan pelatihan serta pengetahuan di dalam menyusun laporan perpajakan, terutama memaksimalkan stimulus dari pemerintah lewat terbitnya aturan pajak melalui PMK 44/PMK/2020 dan perubahannya PMK 86/PMK/2020. Tujuan kegiatan ini adalah agar para pelaku UMKM memiliki kesadaran terhadap kewajiban perpajakan pada UMKM, serta dapat meningkatkan keterampilan dalam manajemen dibidang pemasaran, SDM, produksi dan keuangan serta keterampilan berkomunikasi bagi para pelaku UMKM. Metode yang digunakan dalam kegiatan ini berbentuk pelatihan, pengetahuan, dan sharing session atau penyampaian materi melalui online yang akan disampaikan oleh Tim Cluster Dosen Universitas Widyatama dan Konsultan Pajak YR Konsultan. Hasilnya terjadi peningkatan kesadaran para pelaku UMKM akan pentingnya melaksanakan kewajiban perpajakan dan pengelolaan dibidang pemasaran, SDM, produksi dan keuangan serta keterampilan berkomunikasi, maka hal tersebut akan memberikan dampak baik terhadap peningkatan penerimaan negara dari sisi perpajakan dan peningkatan kualitas para pelaku UMKM.
\end{abstract}

Kata Kunci: pelatihan, stimulus pajak, usaha mikro kecil menengah.

\section{PENDAHULUAN}

Sebelum tahun 2019 usaha Mikro Kecil dan Menengah (UMKM) merupakan sektor ekonomi yang mempunyai peran cukup besar dalam perekonomian nasional, Namun awal tahun 2020 sekarang justru menjadi sektor paling rentan kena hantaman pandemi virus corona. Banyak para UMKM yang mengalami kelesuan usaha dan bahkan gulung tikar. Hal ini disebabkan permintaan produk eksport yang melemah. Meski demikian,
UMKM harus tetap dapat melihat peluang dari kondisi yang ada.

Seiring melesunya perekonomian global membuka peluang bagi UMKM nasional untuk mengisi pasar dalam negeri lebih besar. Dengan kondisi ini dan adanya peluang tersebut, UMKM harus diperkuat karena UMKM tidak lagi dipandang sebagai alternatif, melainkan sebagai tulang punggung atau pondasi ekonomi negara. Dalam rangka memperkuat peranan UMKM perlu adanya kerjasama/sinergi yang baik antara pemerintah dan swasta. 
Analisis situasi dan masalah para pelaku UMKM di Jawa Barat sebagian besar belum mengetahui dan memahami serta memanfaatkan tentang adanya insentif pajak yang diberikan oleh pemerintah melalui PMK 86/2020. PPh final ditanggung oleh pemerintah, sehingga Insentif pajak PPN berupa pengembalian pendahuluan lebih bayar PPN, tanpa proses pemeriksaan pajak sedangkan $\mathrm{PPh}$ untuk pasal 4 dan $\mathrm{PPh}$ pasal 21 pajaknya ditanggung pemerintah, Pemerintah memberikan kompensasi stimulus perpajakan berupa $\mathrm{PPh}$ pasal 4 Ditanggung pemerintah serta $\mathrm{PPh}$ pasal 21 karyawan yang mempunyai gaji dibawah 16jt/bulan yang ditanggung pemerintah. tujuannya agar daya beli UMKM dan perekonomian Indonesia meningkat dengan adanya insentif pajak dimasa Covid 19.

Masalah lain yang muncul yaitu: 1) Mengenai kesadaran masyarakat dalam hal perpajakan. Tingkat kepatuhan wajib pajak dinilai belum terlalu tinggi, sehingga dibutuhkan program yang mampu meningkatkan kesadaran masyarakat dalam hal perpajakan. 2) Kinerja UMKM harus diperbaiki dalam beberapa faktor misalnya, manajemen keuangan, pemasaran, sumber daya manusia, keahlian dibidang komunikasi, dll, agar UMKM dapat bertahan di kondisi Pandemi Corona 19 ini, maka dibutuhkan peran Pemerintah dalam menangani permasalahan tersebut.

Kegiatan yang dilaksanakan ini, tentunya memiliki target dan luaran yang harus dicapai setelah kegiatan selesai dilaksanakan. Adapun target dari pelaksanaan kegiatan pengabdian kepada masyarakat ini adalah meningkatnya pengetahuan dan kesadaran untuk melaksanakan kewajiban perpajakan pada UMKM serta meningkatnya keterampilan dalam manajemen dibidang pemasaran, SDM, produksi dan keuangan serta keterampilan berkomunikasi.

Dengan adanya kegiatan program pengabdian kepada masyarakat yang berupa penyuluhan akan pentingnya taat dalam melaksanakan kewajiban perpajakan ini diharapkan mampu memberi manfaat bagi para UMKM dapat meningkatkan kesadaran UMKM di Wilayah Jawa Barat untuk mulai melaksanakan kewajiban perpajakan untuk UMKM serta dapat meningkatkan keterampilan dalam manajemen dibidang pemasaran, SDM, produksi dan keuangan serta keterampilan berkomunikasi bagi para pelaku UMKM.

\section{METODE}

Metode yang digunakan dalam kegiatan ini yaitu berbentuk: 1) Melalui pelatihan input E-SPT PPh Pasal 21 dan E SPT PPh pasal 4 berikut dengan laporan realisasi PPh 21 DTP dan PPh pasal 4 DTP (di tanggung pemerintah), 2). Melalui pengetahuan aturan PMK 44/2020 yang sudah mengalami perubahan lewat PMK 86/2020 dan PMK 110/2020 tentang pajak yang ditanggung pemerintah akibat dari pandemi covid 19,3). Sharing session yaitu menyediakan waktu dan tempat khusus untuk menggelar kegiatan saling berbagi. Penyampaian materi akan disampaikan oleh Tim Cluster Dosen Universitas Widyatama dan Konsultan Pajak YR Konsultan. Para peserta akan diberikan materi mengenai pengetahuan perpajakan dan sosialisasi tentang insentif Pajak (PMK 44/2020, PMK 86/2020 dan PMK 110/2020).

\section{HASIL DAN PEMBAHASAN}

Sasaran pelaksanaan kegiatan pelatihan dan pengetahuan perpajakan secara online di era pandemi covid 19 ini untuk usaha mikro kecil menengah di Jawa Barat.

Waktu dan tempat akan dilakukan dari tanggal 22 Juni 2020 sampai dengan tanggal 27 Juni 2020, dengan peserta 50 UMKM yang tersebar di Jawa Barat. Adapun pelaksanaan kegiatan akan dilaksanakan secara online karena kondisi pandemi Corona dengan menggunakan aplikasi Zoom.

Kegiatan ini terselenggara atas kerjasama Tim Cluster Universitas Widyatama dengan usaha mikro kecil dan menengah di Jawa Barat berbentuk pelatihan dan pengetahuan yang akan diberikan oleh: 1). Tim Cluster Dosen Universitas Widyatama tentang pengetahuan perpajakan 2). Konsultan Pajak YR Konsultan tentang sosialisasi tentang insentif Pajak (PMK 44/2020 dan PMK 86/2020).

Dampak PKM CSR bagi para pelaku UMKM di Jawa Barat yang dirasakan yaitu ketercapaian terhadap target yang diharapkan, dapat diukur melalui luaran dari kegiatan pengabdian kepada masyarakat sebagai berikut: 1). Para peserta, secata kasat mata terlihat serius dan tertarik untuk menyimak materi yang dipaparkan. 2). Para peserta UMKM mengajak peserta UMKM lain agar memiliki NPWP dan atau mendaftarkan NPWP. 3).

$$
\text { Pendidikan }
$$


Para peserta dapat memberikan edukasi secara sekilas kepada peserta UMKM lain yang tidak mengikuti pelatihan. 4). Dengan meningkatnya kesadaran para pelaku UMKM akan pentingnya melaksanakan kewajiban perpajakan dan pengelolaan dibidang pemasaran, SDM, produksi dan keuangan serta keterampilan berkomunikasi, maka hal tersebut akan memberikan dampak baik terhadap peningkatan penerimaan negara dari sisi perpajakan dan peningkatan kualitas para pelaku UMKM. 5). Keberhasilan penyuluhan tentang penyusunan pelaporan pajak dan keterampilan manajemen pada UMKM bisa menjadi contoh bagi pihak lain sehingga hal ini bisa membantu mewujudkan UMKM taat pajak di Wilayah Jawa Barat dan membantu mewujudkan UMKM yang memiliki daya saing tinggi.

Tingkat kepatuhan Wajib Pajak yang dinilai belum terlalu tinggi, menuntut Direktorat Jenderal Pajak untuk terus melakukan berbagai macam program demi meningkatkan kesadaran masyarakat dalam hal perpajakan. Salah satu program yang dilakukan adalah penyuluhan pajak. Menurut Surat Edaran Direktur Jenderal Pajak Nomor : SE 98/PJ/2011 tentang pedoman penyusunan rencana kerja dan laporan kegiatan penyuluhan perpajakan unit vertikal di lingkungan direktorat jenderal pajak, penyuluhan pajak diartikan sebagai suatu upaya dan proses memberikan informasi perpajakan untuk menghasilkan perubahan pengetahuan, keterampilan, dan sikap masyarakat, dunia usaha, aparat, serta lembaga pemerintah maupun non pemerintah agar terdorong untuk faham, sadar, peduli, dan berkontribusi dalam melaksanakan kewajiban perpajakan.

Penyuluhan pajak merupakan kegiatan yang dilakukan untuk membangun kesadaran, meningkatkan pemahaman, pengetahuan dan wawasan masyarakat mengenai sistem dan peraturan perpajakan yang berlaku, khususnya mengenai bagaimana caranya menjalankan kewajiban perpajakan yang sesuai dengan undangundang, selain itu penyuluhan pajak juga bertujuan untuk meningkatkan kepatuhan pemenuhan kewajiban perpajakan.

Menurut Peratuan Dirjen Pajak Nomor: PER03/PJ/2013 tentang Pedoman Penyuluhan Perpajakan, Penyuluhan Perpajakan bertujuan untuk meningkatkan pengetahuan dan keterampilan perpajakan, serta mengubah perilaku masyarakat Wajib Pajak agar semakin paham, sadar, dan peduli dalam melaksanakan hak dan memenuhi kewajiban perpajakannya.

Agar para pelaku UMKM tetap bertahan ditengah kondisi Pandemi Corona 19. Banyak faktor yang perlu dibenahi misalnya, manajemen keuangan, pemasaran, sumber daya manusia, keahlian dibidang komunikasi, dll. Untuk itu Universitas Widyatama peduli untuk membantu pemerintah dalam memperkuat kineja UMKM tersebut, yang berupa pemberian pelatihan bagi UMKM. Adapun tujuan pelatihan ini adalah, meningkatkan pengetahuan tentang pajak terutama pengenalan PMK 86/2020 yang mengalami perubahan lewat PMK 110/2020 dan meningkatkan keterampilan didalam pembuatan laporan pajak berupa SPT dan pemahaman para pelaku UMKM mengenai regulasi dari insentif pajak tersebut serta pengetahuan lainnya berupa manajemen dibidang pemasaran, SDM, Produksi dan keuangan serta keterampilan berkomunikasi. Pelatihan ini terselenggara atas kerjasama FEB dan dinas Pajak kota Bandung. Pelatihan ini perlu dilakukan mengingat masih belum pahamnya UMKM tentang pajak,

Potensi Keberlangsungan berikutnya akan dilakukan pelatihan dan pengetahuan di bidang Marketing serta pengelolaan keuangan bagi pelaku PKM CSR UMKM di Jawa Barat.

Program CSR - PKM yang inovatif yaitu: 1). Mengadakan pelatihan pengisian E-Billing kepada para pelaku UMKM. 2). Mengadakan sosialisasi mengenai aturan perpajakan terbaru yang diterapkan oleh Pemerintah saat ini yaitu mengenai Peraturan Menteri Keuangan Republik Indonesia No 44/PMK.03/2020) bagi para pelaku UMKM. 3) Mengadakan sosialisasi mengenai pembayaran $\mathrm{PPh}$ Pasal 23 untuk badan. 


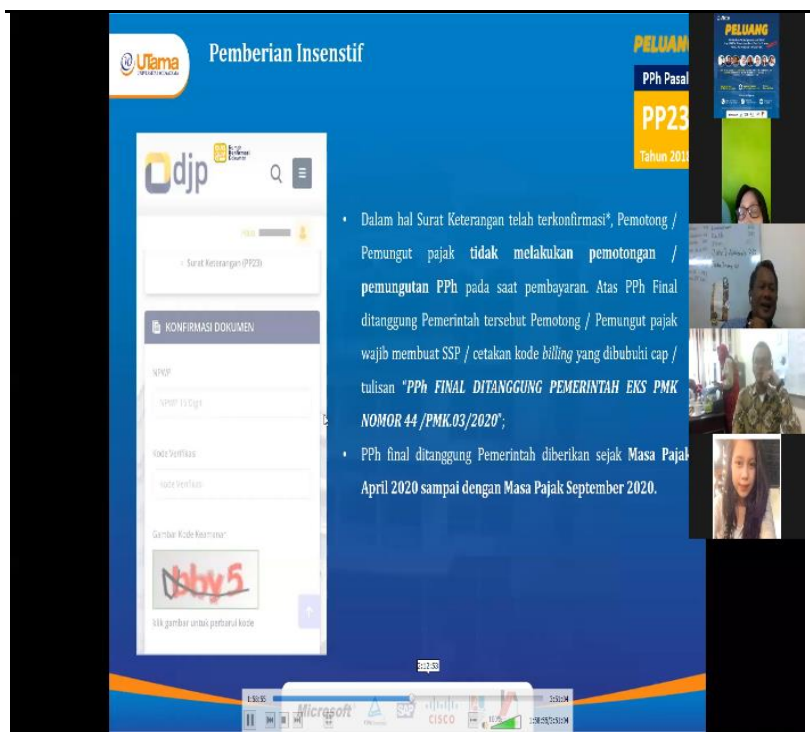

Gambar 1 (Sosialisasi Pemberian Insentif Pajak)

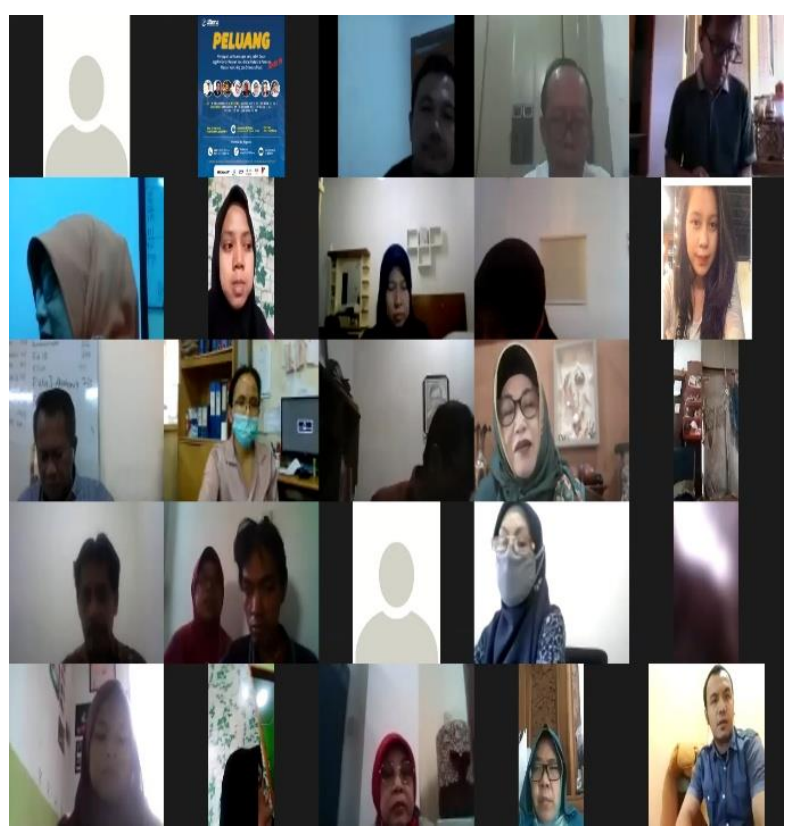

Gambar 2 (acara kegiatan pelaksanaan lewat aplikasi Zoom )

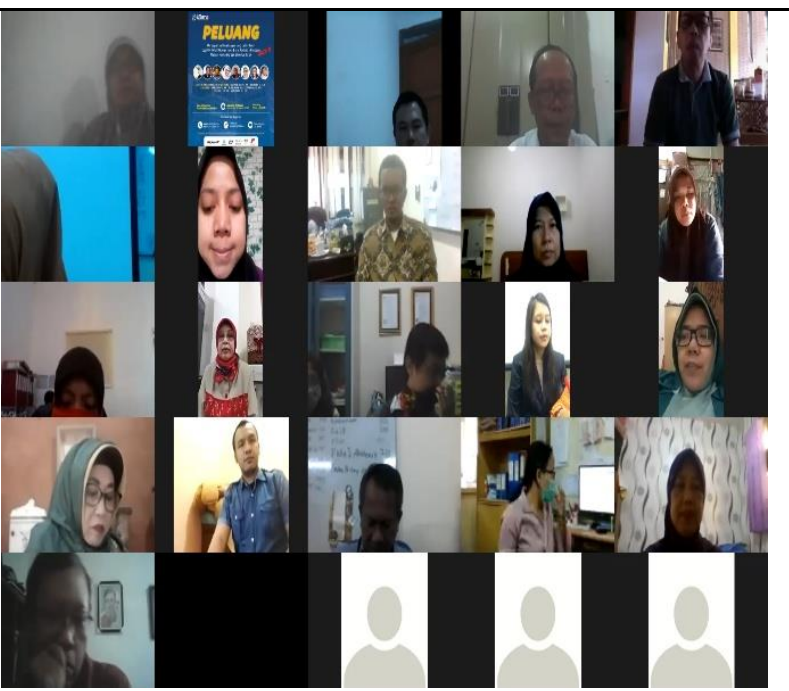

Gambar 3 (pemaparan materi lewat aplikasi Zoom )

\section{KESIMPULAN}

Berdasarkan hasil kegiatan pengabdian kepada masyarakat yang telah dilaksanakan, dapat disimpulkan bahwa kegiatan ini memberikan implikasi dan dampak yang positif bagi UMKM yaitu menambah pengetahuan serta keterampilan khususnya mengenai perpajakan serta diharapkan dapat meningkatkan keterampilan dalam manajemen dibidang pemasaran, SDM, produksi dan keuangan serta keterampilan berkomunikasi bagi para pelaku UMKM.

Adapun saran yang dapat kami sampaikan adalah sebagai berikut:

1. Menerapkan atau mengaplikasikan pengetahuan yang telah didapat dari hasil penyuluhan baik kepada internal badan usaha UMKM maupun ke eksternal atau masyarakat lainnya.

2. Mengembangkan materi penyuluhan yang didapat mengenai perpajakan dan keterampilan manajemen dibidang pemasaran, SDM, Produksi dan keuangan serta keterampilan berkomunikasi pada UMKM, seperti penyuluhan tentang perencanaan pajak bagi UMKM dan manajemen pemasaran,SDM, produksi dan keuangan serta kerampilan berkomunikasi bagi UMKM. 


\section{UCAPAN TERIMAKASIH}

Ucapan terima kasih kepada:

1). Rektor Universitas Widyatama Bapak Prof., Dr., H. Obsatar Sinaga, S.Ip. M.S.i, selaku Rektor Universitas Widyatama 2.) Ibu R. Adjeng Mariana F Hj., Dr., S.E., M.M., selaku Dekan Fakultas Ekonomi dan Bisnis Universitas Widyatama. 3) Ibu Ratna Komala Putri., Dr., S.E., M.Si selaku kepala P2M Universitas Widyatama. 4) Ibu Sri Wiludjeng Sunu Purwaningdyah, S.E., M.P sebagai ketua cluster pengabdian pada masyarakat universitas Widyatama. 5). Para pelaku usaha mikro kecil menengah di Jawa Barat.

\section{REFERENSI}

Peratuan Dirjen Pajak Nomor: PER-03/PJ/2013 tentang Pedoman Penyuluhan Perpajakan, Penyuluhan Perpajakan bertujuan untuk meningkatkan pengetahuan dan keterampilan perpajakan
PMK 44/2020 tentang insentif pajak untuk wajib pajak yang terdampak pandemi covid Virus disease 2019.

PMK 86/2020 tentang insentif pajak untuk wajib pajak yang terdampak pandemi covid Virus disease 2019.

PMK 110/2020 tentang perubahan PMK $86 / 2020$ insentif pajak untuk wajib pajak yang terdampak pandemi covid Virus disease 2019.

Surat Edaran Direktur Jenderal Pajak Nomor: SE -98/PJ/2011 tentang pedoman penyusunan rencana kerja dan laporan kegiatan penyuluhan perpajakan unit vertikal di lingkungan direktorat jenderal pajak 